\title{
Seasonal Variation of Kaurenoic Acid, a Hypoglycemic Diterpene Present in Wedelia paludosa (Acmela brasiliensis) (Asteraceae)
}

Louisiane Faccio V. Bresciani ${ }^{\mathrm{a}}$, Rosendo Augusto Yunes ${ }^{\mathrm{a}}$, Cristiani Bürger ${ }^{\mathrm{b}}$, Luis Eduardo De Oliveira ${ }^{\mathrm{b}}$, Kauê Leal Bóf ${ }^{\mathrm{b}}$, and Valdir Cechinel-Filho ${ }^{\mathrm{b}, *}$

a Departamento de Química, Universidade Federal de Santa Catarina (UFSC), 88040-900, Florianópolis, SC, Brazil

b Núcleo de Investigações Químico-Farmacêuticas (NIQFAR), CCS, Universidade do Vale do Itajaí (UNIVALI), 88302-202, Itajaí, SC, Brazil. Fax: 55021473417601.

E-mail: cechinel@univali.br

* Author for correspondence and reprint requests

Z. Naturforsch. 59c, 229-232 (2004); received August 14/September 17, 2003

We evaluated the variation of the concentration of kaurenoic acid (1), which is a bioactive diterpene, in leaves, flowers, stems and roots from Wedelia paludosa (Acmela brasiliensis) for different seasons using the HRGC/FID method. The results indicated that the concentration of $\mathbf{1}$ is higher in the roots and stems during the autumn. The pharmacological results suggested that kaurenoic acid is responsible, at least in part, for the hypoglycemic potential detected in this plant.

Key words: Wedelia paludosa, Kaurenoic Acid, Hypoglycemic Effect

\section{Introduction}

Kauranes consist of a class of diterpenes which contain a rigid tetracyclic skeleton. They are also intermediates in the biosynthesis of the gibberellins, which are plant growth hormones of several plants, some fungal metabolites and diterpene alkaloids (Ghisalberti, 1997). Antimicrobial, antiparasitic, insect antifeedant, anti-HIV and antiinflammatory activities have been reported for different kauranes (Rezende et al., 2000). Ent-16kauren-19-oic acid or kaurenoic acid (1) is one of the most important members of this family, exhibiting interesting biological properties, including analgesic (Block et al., 1998a,b), antifungal (Sartori et al., 2003) and smooth muscle relaxant (De Alencar Cunha et al., 2003) effects.

It is well-distributed in several species of plants, including those belonging to the genus Xylopia (Annonaceae) (Takahashi et al., 1995), Mikania (Nascimento and Oliveira, 2001), Annona (Oliveira et al., 2002) and Wedelia (Asteraceae) (Bresciani et al., 2000).

Recently, we determined the variation of $\mathbf{1}$ in the leaves, flowers, stems and roots of W. paludosa (Bresciani et al., 2000), reclassified as Acmela brasiliensis (Asteraceae). In this work, we present the results of the study of the concentration of kaurenoic acid (1) in leaves, flowers, stems and roots in relation to different seasons, using the HRGC/FID method. We also demonstrate for the first time, its hypoglycemic effect when administered to diabetic rats.

\section{Material and Methods}

\section{Plant material}

The plant was always collected at the same place, next to the Department of Chemistry/ UFSC, on the following dates: 05/1998 (autumn), 08/1998 (winter), 12/1998 (spring) and 01/2001 (summer). The plant was dried at room temperature and then separated into flowers, stems, roots and leaves.

\section{Methodology of extraction}

The different parts of the plant $(2.0 \mathrm{~g}$ each $)$ were cut in small pieces and macerated with $n$-hexane (about $150 \mathrm{ml}$ ) at room temperature for $5 \mathrm{~d}$. At the end of this period, the extracts were filtered and concentrated to a volume of $1-2 \mathrm{ml}$, and stored in a freezer. The samples were silylated with BSTFA [bis(trimethyl-silyl)trifluoro-acetamide] for direct HRGC analysis.

\section{Chromatographic analysis}

The chromatographic analyses were performed on a GC-14 A Shimadzu equipped with a $30 \mathrm{~m} \times$ $0.25 \mathrm{~mm}$ i.d. column coated $(0.3 \mu \mathrm{m}$ film thickness $)$ 
with cross-linked polymethylsiloxane as stationary phase (column LM-1; L\&M, São Carlos, Brazil). Samples were introduced using the "splitless mode" (1 min, $1.0 \mu \mathrm{l}$ injection volume) with a flame ionization detector (FID) temperature at $320^{\circ} \mathrm{C}$ and a column temperature programming from $40{ }^{\circ} \mathrm{C}$ at $8^{\circ} \mathrm{C} / \mathrm{min}$ to $310^{\circ} \mathrm{C}$ (held for $10 \mathrm{~min}$ ). Hydrogen was used as the carrier gas. The data were processed using the Cromatografia program (Microquímica, Florianópolis, Brazil). Each determination was carried out in duplicate at least. Highly-pure kaurenoic acid (>98\%) was used for calibration curves after silylation. The standard compound was previously isolated from this same plant (Block et al., 1998a; Bresciani et al., 2000).

\section{Animals}

Male Wistar rats, weighing 200-300 g, were housed in standard environmental conditions at a temperature of $23 \pm 2{ }^{\circ} \mathrm{C}$, relative humidity and a $12 \mathrm{~h}$ light/dark cycle. They were fed on a standard pellet diet and tap water was given ad libitum during the experimental period.

\section{Biological assay}

The rats with blood glucose concentrations of $90-100 \mathrm{mg} / \mathrm{dl}$ were divided into groups with 6 rats each. Prior to each study, the animals were subjected to fasting for $18 \mathrm{~h}$ (Alarcon-Aguilar et al., 1998). Diabetes was induced in rats by single intraperitoneal administration of alloxan monohydrate $(180 \mathrm{mg} / \mathrm{kg})$ (Al-Shamaony et al., 1994). After $3 \mathrm{~d}$, the blood was collected (from fasting animals) and the glucose was determined by the glucose oxidase method using commercial kits. The animals with blood glucose levels above $150 \mathrm{mg} / \mathrm{dl}$ were separated for the oral glucose tolerance. All the groups received glucose $(5 \mathrm{~g} / \mathrm{kg})$ after collecting the first blood sample. Blood was collected 1, 2, 4 and $6 \mathrm{~h}$ after the glucose ingestion. Group I was a normoglycemic control in which normal animals received saline solution $(0.9 \%$ $\mathrm{NaCl}, 3 \mathrm{ml} / \mathrm{kg}$ ). Groups II, III and IV were alloxan-induced diabetic rats. Group II was used as a hyperglycemic control and received saline solution $(0.9 \% \mathrm{NaCl}, 3 \mathrm{ml} / \mathrm{kg})$; group III received glibenclamide $(40 \mathrm{mg} / \mathrm{kg})$ as a reference drug; group III received kaurenoic acid (1) $(10 \mathrm{mg} / \mathrm{kg})$ isolated from W. paludosa (Block et al., 1998a).

\section{Statistical analysis}

The data are expressed as the mean \pm S. D. The significance of the difference between the mean values for the test and control studies was established by analysis of variance (ANOVA) followed by the Dunnett test.

\section{Results and Discussion}

Several analytical methods can be used for the quality control of plants, however, gas chromatography is the technique which has been most used and with greater success for the extracts and phytotherapeutic standardization (Vilegas et al., 1995; Bauer and Tittel, 1996; Cechinel Filho and Yunes, 1998).

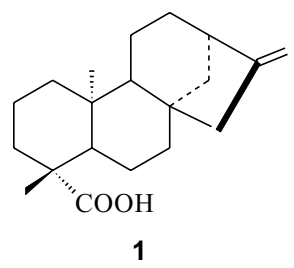

The seasonal variation of kaurenoic acid (1) can be seen in Table I, which indicates the profile of its concentration at different parts of the plant for different seasons. It can be noted that the variation of $\mathbf{1}$ in the different seasons (autumn, winter, spring and summer) was fairly accentuated. The amounts of $\mathbf{1}$ are higher in the roots and stems during the autumn. This fact suggests that kaurenoic acid (1) may be the precursor for other groups of compounds with biological function of growth, such as gibberellins (Ghisalberti, 1997).

Our research group previously showed that the hydroalcoholic extract and, specially hexane fraction, exhibit pronounced hypoglycemic properties indicating that non-polar components could be acting on the glycemia (Novaes et al., 2001; Dutra et al., 2001). For this reason, we have now eval-

Table I. Seasonal variation of kaurenoic acid (1) present in different parts of W. paludosa.

\begin{tabular}{|c|c|c|c|c|}
\hline \multirow{2}{*}{$\begin{array}{l}\text { Parts of } \\
\text { plant }\end{array}$} & \multicolumn{4}{|c|}{ Mass fraction of kaurenoic acid } \\
\hline & Autumn & Winter & Spring & Summer \\
\hline Roots & 6.65 & 0.0049 & 1.35 & 0.101 \\
\hline Stems & 4.96 & 0.0735 & 0.037 & 0.0142 \\
\hline Leaves & 1.06 & 0.052 & 0.114 & 0.288 \\
\hline Flowers & 1.04 & 0.856 & 0.301 & 0.0255 \\
\hline
\end{tabular}


Table II. Effect of kaurenoic acid (1), saline (control), or glibenclamide on blood glucose levels in alloxan-induced diabetic rats.

\begin{tabular}{lclllll}
\hline & Basal value & $1 \mathrm{~h}$ & $2 \mathrm{~h}$ & $4 \mathrm{~h}$ & $6 \mathrm{~h}$ \\
\hline $\begin{array}{l}\text { Normal control } \\
(\mathrm{n}=9)\end{array}$ & $64.02 \pm 13.58$ & $126.92 \pm 28.43^{* *}$ & $113.29 \pm 13.21^{* *}$ & $113.28 \pm 23.92^{* *}$ & $78.15 \pm 14.02$ \\
$\begin{array}{l}\text { Hyperglycemic control } \\
(\mathrm{n}=6)\end{array}$ & $325.33 \pm 80.9$ & $448.11 \pm 91.8$ & $502.59 \pm 124.4^{*}$ & $539.58 \pm 122.28^{*}$ & $577.4 \pm 139.03 * *$ \\
$\begin{array}{l}\text { Glibenclamide }(40 \mathrm{mg} / \mathrm{kg}) \\
(\mathrm{n}=6)\end{array}$ & $256.56 \pm 38.59$ & $470.52 \pm 100.75^{* *}$ & $434.3 \pm 99.08^{* *}$ & $365.53 \pm 53.95$ & $332.03 \pm 69.93$ \\
$\begin{array}{l}\text { Kaurenoic acid }(10 \mathrm{mg} / \mathrm{kg}) \\
(\mathrm{n}=5)\end{array}$ & $316.92 \pm 130.05$ & $587.58 \pm 78.27 * *$ & $413.26 \pm 131.33$ & $421.92 \pm 112.99$ & $296.75 \pm 78.09$ \\
\hline
\end{tabular}

$* \mathrm{p}<0.05 ; * * \mathrm{p}<0.01$ (Dunnett test).

uated the hypoglycemic potential of $\mathbf{1}$. As shown in Table II, in alloxan-induced diabetic rats compound $\mathbf{1}$ at $10 \mathrm{mg} / \mathrm{kg}$ presented significant and considerable effects on glucose levels in relation to the control group, being more efficacious than the hydroalcoholic extract and hexane fraction, studied previously (Novaes et al., 2001; Dutra et al., 2001). It also lowered the glucose blood levels more rapidly than glibenclamide, used here as a reference drug, in the period analyzed. This suggests that $\mathbf{1}$ is contributing to the hypoglycemic activity of $W$. paludosa. Although preliminary, these results are of particular interest, considering the increasing search by the pharmaceutical industries to discover new and effective clinical agents for the treatment of diabetes mellitus, which is a chronic disease characterized by high blood glucose levels caused by inadequate insulin secretion or impaired insulin action (Mandrup-Poulsen, 1998; Venkatesh et al., 2003). Another important fact is the high yield of compound $\mathbf{1}$ in W. palu$d o s a$, which may be used as start material to obtain more potent derivatives. Thus, considering the previous biological properties described for Wedelia paludosa (Acmela brasiliensis), in some case directly related to the presence of kaurenoic acid (1), the determination of the best season for its production is suitable for standardization of the extracts of this plant and their phytopreparations. The determination of $\mathbf{1}$ as the main active principle is a potential help in future pre-clinical and clinical investigation. However, other studies are required because it is well-known that the secondary metabolites are influenced, either qualitatively or quantitatively, by the age of the plant, variety, soil type, apprenticeship of development of the plant and climatic conditions (Cechinel Filho and Yunes, 1998; Hook et al., 1999).

\section{Acknowledgements}

The authors are grateful to $\mathrm{CNPq}$ (Brazil) for financial support. 
Alarcon-Aguilar F. L., Roman-Ramos R., and PerezGutierrez S. (1998), Study of the anti-hyperglycemic effect of plants used as antidiabetics. J. Ethnopharmacol. 61, 101-110.

Al-Shamaony L., Al-Khazraji S. M., and Twaaij H. A. A. (1994), Hypoglycemic effect of Artemisia herba alba, II: Effect of a valuable extract on some blood parameters in diabetic animals. J. Ethnopharmacol. 43, 167171.

Bauer R. and Tittel G. (1996), Quality assessment of herbal preparations as a precondition of pharmacological and clinical studies. Phytomedicine 2, 193-198.

Block L. C., Santos A . R. S., Souza M. M., Scheidt C., Yunes R. A ., Santos M. A., Delle Monache F., and Cechinel-Filho V. (1998a), Chemical and pharmacological examination of antinociceptive constituents of Wedelia paludosa. J. Ethnopharmacol. 61, 85-89.

Block L. C., Scheidt C., Quintão N. L. M., Santos A. R. S., and Cechinel-Filho V. (1998b), Phytochemical and pharmacological analysis of different parts of Wedelia paludosa DC. (Compositae). Pharmazie 53, 716-718.

Bresciani L. F. V., Cechinel-Filho V., and Yunes R. A. (2000), Comparative study of different parts of Wedelia paludosa by gas chromatography. Nat. Prod. Lett. 14, 247-254.

Cechinel Filho V. and Yunes R. A. (1998), Estratégias para obtenção de compostos farmacologicamente ativos a partir de plantas medicinais. Conceitos sobre modificação estrutural para otimização da atividade. Quim. Nova. 21, 99-105.

De Alencar Cunha K. M., Paiva L. A., Santos F. A., Gramosa N. V., Silveira E. R., and Rao V. S. (2003), Smooth muscle relaxant effect of kaurenoic acid, a diterpene from Copaifera langsdorffii on the rat uterus in vitro. Phytother. Res. 17, 320-324.

Dutra D., Santos M. R. S., Pascua C. O., Cechinel Filho V., and Bürger C. (2001), Avaliação da ação antidiabética de frações semipurificadas de Wedelia paludosa. Rev. Alcance (UNIVALI) 8, 9-14.

Ghisalberti E. L. (1997), The biological activity of naturally occurring kaurane diterpenes. Fitoterapia 68, $303-325$.
Hook I., Poupat C., Ahond A., Guénard D., Guéritte F., Adeline M. T., Wang X. P., Dempsey D., Breuillet S., and Potier P. (1999), Seasonal variation of neutral and basic taxoid contents in shoots of European yew (Taxus baccata). Phytochemistry 52, 1041-1045.

Mandrup-Poulsen T. (1998), Diabetes. BMJ 316, 1221 1225 .

Nascimento A. M. and Oliveira C. R. (2001), Kaurene diterpenes and other chemical constituents from $\mathrm{Mi}$ kania stipulacea (M. Vahl) Willd. J. Braz. Chem. Soc. 12, 552-555.

Novaes A. P., Rossi C., Poffo C., Pretti Junior E., Oliveira A. E., Schlemper V., Niero R., Cechinel Filho V., and Bürger C. (2001), Preliminary evaluation of the hypoglycemic effect of some Brazilian medicinal plants. Thérapie 56, 427-430.

Oliveira B. H., Santana A. E., and Bastos D. Z. (2002), Determination of the diterpenoid, kaurenoic acid in Annona glabra by HPLC. Phytochem. Anal. 13, 368-371.

Rezende M. C., Urzua A., Bortoluzzi A. J., and Vásquez L. (2000), Variation of the antimicrobial activity of Pseudognaphalium vira vira (Asteraceae): isolation and X-ray structure of ent-3 $\beta$-hydroxy-16-kauren-19oic acid. J. Ethnopharmacol. 72, 459-464.

Sartori M. R. K., Pretto J. B., Cruz A. B., Bresciani L. F. V., Yunes R. A., Sortino M., Zacchino S. A., and Cechinel Filho V. (2003), Antifungal activity of fractions and two pure compounds of flowers from Wedelia paludosa (Acmela brasiliensis) (Asteraceae). Pharmazie 58, 567-569.

Takahashi J. A., Boaventura M. A. D., Bayma J. C., and Oliveira A. B. (1995), Frutoic acid, a dimeric kaurane diterpene from Xylopia frutescens. Phytochemistry 40, 607.

Venkatesh S., Reddy D. G., Reddy B. M., Ramesh M., and Appa Rao A. V. N. (2003), Antihyperglycemic activity of Caralluma attenuata. Fitoterapia 74, 274-279.

Vilegas J. H. Y., Lanças F. M., and Antoniosi Filho N. R. (1995), High temperature capillary GC analysis of phytopreparations of "espinheira santa" (Maytenus ilicifolia M., and Maytenus aquifolium M. - Celastraceae). Chromatographia 40, 341-344. 